\title{
Screening of BARI Rhizobium Biofertilizers against Foot and Root Rot of Chickpea
}

\author{
K. M. Khalequzzaman* \\ Senior Scientific Officer (Plant Pathology), Spices Research Centre, BARI, Shibganj, Bogra, BANGLADESH \\ *Corresponding Contact: \\ Email: zaman.path@gmail.com \\ Cell Phone: +8801911762978
}

\begin{abstract}
The experiment was conducted at the sick plot, Pulses Research Centre, Ishurdi, Pabna, Bangladesh during two consecutive years of 2010-11 and 2011-12 to screen out the effective BARI Rhizobium Biofertilizers against foot and root rot of chickpea. Six BARI Rhizobium strains viz. BARI Rca 201, BARI Rca 220, BARI Rca 202, BARI chickpea Rajshahi, BARI Rca IC 59 and BARI Chickpea pulse 1 were used as treatments. In 2010-11, foot and root rot incidence ranged from $9.78-26.63 \%$, while the lowest incidence was recorded in BARI Chickpea Rajshahi, but the highest incidence was recorded in untreated control. BARI Chickpea Rajshahi gave the highest plant survival $(90.22 \%)$ and control treatment gave the lowest plant survival $(72.55 \%)$. BARI Chickpea Rajshahi treated plots reduced maximum foot and root rot incidence $(63.27 \%)$ over untreated control. Similar trends of the results were observed in 201112. The highest yield was obtained from BARI Chickpea Rajshahi with 2090 and 2040 $\mathrm{kg} /$ ha during 2010-11 and 2011-12, respectively, and the lowest yield was obtained from untreated control for both the years.
\end{abstract}

Keywords: Screening, Rhizobium biofertilizers, foot and root rot, yield, chickpea

9/10/2015

Source of Support: Nil, No Conflict of Interest: None Declared

How to Cite: Khalequzzaman K. M. 2015. Screening of BARI Rhizobium Biofertilizers against Foot and Root Rot of Chickpea $A B C$ Journal of Advanced Research, 4, 99-106.

This article is is licensed under a Creative Commons Attribution-NonCommercial 4.0 International License.

Attribution-NonCommercial (CC BY-NC) license lets others remix, tweak, and build upon work non-commercially, and

although the new works must also acknowledge \& be non-commercial.

\section{INTRODUCTION}

Chickpea (Cicer arietinum) is cultivated as sole and intercrops. It is the third major pulse crops of Bangladesh in respect of acreage and production. Chickpea is consumed as a dry pulse crop, but also snack foods, sweets, condiments even as green vegetable in the world. Chickpeas contain protein, complex carbohydrates, and fibre, while low in fat and cholesterol. Seeds contain average about $20 \%$ protein, $5 \%$ fat and $55 \%$ carbohydrate (Nikam et al., 2007). The production of chickpea is decreasing every year due to cultural and genetic factors, susceptibility to disease, and delay in sowing by the farmers (Anonymous, 1989). The average yield of chickpea is also low due to various diseases. Among the diseases, foot and root rot of chickpea caused by Fusarium oxysporum and Sclerotium rolfsii (Dey et al., 1993) are common and the most serious disease in Bangladesh. It causes seedling death at early stage resulting very poor plant stand that ultimately produces very low yield. 
Foot and root rot disease of many crops caused by Fusarium oxysporum and Sclerotium rolfsii which are soil-borne pathogens commonly occurs in the tropical and sub-tropical regions of the world (Aycock, 1966). The fungi can attack the crop during any time from seedling to the flowering stage and are comparatively more destructive at the seedling stage. Foot and root rot diseases may cause $100 \%$ seedling mortality in monoculture under conducive weather conditions for disease development (Begum, 2003). The pathogenic fungi are soilborne in nature; hence, seed treatment with Rhizobium Biofertilizers might be effective in controlling foot and root rot disease and increasing grain yield of chickpea. Moreover, by seed treatment, very low quantities of Biofertilizer are required compared to a foliar application with fungicides. Again, it reduces the risk of environmental pollution, health hazard and not much costly to the growers. Some bacteria associated with the roots of crop plants have beneficial effects on their host, and are referred to as plant growth promoting rhizobacteria (PGPR) (Kloepper and Schroth, 1978). The rhizosphere is subjected to dramatic changes and its dynamic nature creates interactions that result in biocontrol of diseases (Rovira, 1965 \& 1969). PGPR (free living bacteria) affects on plant growth and disease suppression. Rhizobium may reduce growth of pathogens in the rhizosphere area. Integrated use of Vitavax 200 and biocontrol agents was effective in improving seedling emergence and yield as well as in reducing wilt incidence of chickpea (Gupta, 2006). Treatment of seeds with Biofertilizer resulted in 85.2 and $73.1 \%$ reduction in death of plants due to infection by Fusarium oxysporum in lentil and chickpea, respectively (Hossain, 2000). Treatment of seed with Rhizobium strains significantly reduced the incidence of damping off and increased seedling height of chickpea (Huang and Erickson, 2007). Rhizobium strain BINAR P36 largely controlled the foot and root rot and produced higher green pod yield of Bush bean (Khalequzzaman and Hossain, 2008). It has been observed that Rhizobium also reduced foot and root rots of leguminous crops. Bangladesh Agricultural Research Institute (BARI) has developed some peat based Rhizobium Biofertilizers. Among the BARI Rhizobium Biofertilizers, which Rhizobium Biofertilizers are effective in controlling foot and root rot of chickpea would be found out. These types of research work are needed in Bangladesh. So, the present study was undertaken to screen out the effective BARI Rhizobium Biofertilizers against foot and root rot and yield of chickpea.

\section{Materials AND Methods}

The experiment was conducted in the sick plot at Pulses Research Centre, Bangladesh Agricultural Research Institute (BARI), Ishurdi, Pabna, Bangladesh during two consecutive years of 2010-11 and 2011-12. The experimental plot was prepared with five ploughings and cross ploughings followed by laddering to break the clods as well as level the soil. The weeds and stubbles of previous crops were collected and removed from the soil. No any chemical fertilizers were applied. The experiment was carried out following Randomized Complete Block Design with three replications. The unit plot size was $1.6 \mathrm{~m} \times 1.5 \mathrm{~m}$ and plant spacing was $40 \mathrm{~cm}$ with continuous sowing for the experiment. Six BARI Rhizobium Biofertilizers viz. BARI Rca 201, BARI Rca 220, BARI Rca 202, BARI chickpea Rajshahi, BARI Rca IC 59 and BARI Chickpea pulse 1 were used as treatments. Chickpea variety BARIchola 1 was used in this experiment. Seeds were initially moistened with molasses at the rate of 40 $\mathrm{g}$ per $\mathrm{kg}$ seed and then the seeds were thoroughly mixed with peat based BARI Rhizobium Biofertilizers @ 40 g per kg seed before sowing, where biofertilizer contained $10^{8}$ Rhizobial cells/mg (Somasegaran and Hoben, 1994). The inoculant-coated seeds were sown at the afternoon on November 9, 2010, and November 16, 2011, respectively, and furrow was filled up just after seed sowing. Intercultural operations were done as per needed and to maintain 
the normal hygienic condition of crop in the field. During the growing period, the plots were regularly inspected to record the incidence of foot and root rot disease from seedling to maturity stage of the crop. Dead plants were counted and removed from the field. Disease plant parts were collected and brought into the laboratory for identifying foot and root rot causal pathogens. The crop was harvested on March 16, 2011, and March 20, 2012, respectively. Data were recorded on foot and root rot, plant survival, plant height, number of pods/plant, number of seeds/plant, weight of seeds/plant and yield (kg/ha). The incidence of foot and root rot of lentil was recorded at every alternate day. The incidence of foot and root rot of chickpea was calculated by the following formula:

Number of infected plants

Incidence of foot and root rot $(\%)=$ $\times 100$

\section{Total number of plants}

The recorded data were analyzed statistically to find out the level of significance and the variations among the respective data were compared following Duncan's New Multiple Range Test (DMRT) according to Gomez and Gomez (1984).

\section{Results AND Discussion}

Results of BARI Rhizobium Biofertilizers on foot and root rot and plant height of chickpea during 2010-11 are presented in Table 1. BARI Rhizobium strains showed a significant effect on foot and root rot of chickpea. Foot and root rot incidence ranged from 9.78-26.63\%, while the lowest incidence was recorded in BARI Chickpea Rajshahi, which was not statistically similar to all other treatment, but the highest incidence was recorded in untreated control. BARI Chickpea Rajshahi gave the highest plant survival $(90.22 \%)$, and control treatment gave the lowest plant survival (72.55\%). BARI Chickpea Rajshahi treated plots reduced maximum foot and root rot incidence $(63.27 \%)$ over untreated control followed by BARI Rca IC 59 and BARI Chickpea pulse 1. Plant height was not significantly influenced by Rhizobium strains. BARI Rca IC 59 gave the highest plant height $(57.70 \mathrm{~cm})$ and BARI Rca 202 resulted the lowest $(55.20 \mathrm{~cm})$ plant.

Table 1: Effect of BARI Rhizobium Biofertilizers on foot and root rot and plant height of Chickpea during 2010-11

\begin{tabular}{|l|c|c|c|c|}
\hline $\begin{array}{l}\text { Rhizobium } \\
\text { Biofertilizers }\end{array}$ & $\begin{array}{c}\text { Foot and } \\
\text { root rot } \\
\mathbf{( \% )}\end{array}$ & $\begin{array}{c}\text { Plant } \\
\text { Survival } \\
\mathbf{( \% )}\end{array}$ & $\begin{array}{c}\text { Disease } \\
\text { reduction over } \\
\text { control (\%) }\end{array}$ & $\begin{array}{c}\text { Plant } \\
\text { height } \\
\text { (cm) } \mathbf{N S}\end{array}$ \\
\hline BARI Rca 201 & $15.57 \mathrm{~b}$ & 84.43 & 41.53 & 55.40 \\
\hline BARI Rca 220 & $16.18 \mathrm{~b}$ & 83.82 & 39.24 & 58.20 \\
\hline BARI Rca 202 & $15.81 \mathrm{~b}$ & 84.19 & 42.99 & 55.20 \\
\hline BARI Chickpea Rajshahi & $9.78 \mathrm{c}$ & 90.22 & 63.27 & 56.33 \\
\hline BARI Rca IC 59 & $13.78 \mathrm{~b}$ & 86.22 & 48.25 & 57.70 \\
\hline BARI Chickpea pulse 1 & $14.16 \mathrm{~b}$ & 85.84 & 46.82 & 57.53 \\
\hline Control (Untreated) & $26.63 \mathrm{a}$ & 73.37 & - & 56.87 \\
\hline
\end{tabular}

In a column, similar letter does not differ significantly at $5 \%$ level of probability.

BARI = Bangladesh Agricultural Research Institute

NS $=$ Not Significant

Results of BARI Rhizobium Biofertilizers on foot and root rot and plant height of chickpea during 2011-12 are presented in Table 2. BARI Rhizobium strains showed a significant effect on foot and root rot of chickpea. Foot and root rot incidence ranged from $8.90-27.45 \%$, 
while the lowest incidence was recorded in BARI Chickpea Rajshahi, that were not statistically similar to all other treatments but the highest incidence was observed in untreated control. BARI Chickpea Rajshahi gave the highest plant survival $(91.10 \%)$, and control treatment gave the lowest plant survival (72.55\%). BARI Chickpea Rajshahi treated plots reduced maximum foot and root rot incidence $(67.58 \%)$ over untreated control. Plant height was not significantly influenced by Rhizobium strains. BARI Rca IC 59 gave the tallest plant $(56.25 \mathrm{~cm})$ and BARI Rca 201 resulted the smallest $(52.07 \mathrm{~cm})$.

Table 2: Effect of BARI Rhizobium Biofertilizers on foot and root rot and plant height of Chickpea during 2011-12

\begin{tabular}{|l|c|c|c|c|}
\hline $\begin{array}{l}\text { Rhizobium } \\
\text { Biofertilizers }\end{array}$ & $\begin{array}{c}\text { Foot and } \\
\text { root rot } \\
\mathbf{( \% )}\end{array}$ & $\begin{array}{c}\text { Plant } \\
\text { survival } \\
\mathbf{( \% )}\end{array}$ & $\begin{array}{c}\text { Disease } \\
\text { reduction over } \\
\text { control (\%) }\end{array}$ & $\begin{array}{c}\text { Plant } \\
\text { Height } \\
\text { (cm) } \mathbf{N S}\end{array}$ \\
\hline BARI Rca 201 & $18.01 \mathrm{~cd}$ & 81.99 & 34.39 & 52.07 \\
\hline BARI Rca 220 & $21.82 \mathrm{~b}$ & 78.18 & 20.51 & 53.40 \\
\hline BARI Rca 202 & $19.99 \mathrm{bc}$ & 80.01 & 27.18 & 52.53 \\
\hline BARI Chickpea Rajshahi & $8.90 \mathrm{f}$ & 91.10 & 67.58 & 52.53 \\
\hline BARI Rca IC 59 & $14.41 \mathrm{e}$ & 85.59 & 47.51 & 56.25 \\
\hline BARI Chickpea pulse 1 & $16.67 \mathrm{de}$ & 83.33 & 29.27 & 54.27 \\
\hline Control (Untreated) & $27.45 \mathrm{a}$ & 72.55 & - & 54.30 \\
\hline
\end{tabular}

In a column, similar letter does not differ significantly at $5 \%$ level of probability. BARI = Bangladesh Agricultural Research Institute

NS $=$ Not Significant

Results of BARI Rhizobium Biofertilizers on on yield and yield contributing characters of Chickpea during 2010-11 are presented in Table 3. Number of pod/plant, number of seeds/plant, weight of seeds/plant and yield under BARI Rhizobium strains varied significantly from one to another. The highest number of pod/plant (47.80), number of seeds/plant (71.63), weight of seeds/plant (9.58 g) and yield (2090 kg/ha) were obtained from BARI Chickpea Rajshahi which was followed by BARI Rca IC 59 and BARI Chickpea pulse, and the lowest of these parameters were obtained from untreated control.

Table 3: Effect of BARI Rhizobium Biofertilizers on yield and yield contributing characters of Chickpea during 2010-11

\begin{tabular}{|l|c|c|c|c|}
\hline Rhizobium Biofertilizers & $\begin{array}{c}\text { No. of pod } \\
\text { /plant }\end{array}$ & $\begin{array}{c}\text { No. of seed } \\
\text { /plant }\end{array}$ & $\begin{array}{c}\text { Wt. of seed } \\
\text { /plant (g) }\end{array}$ & $\begin{array}{c}\text { Yield } \\
\text { (kg/ha) }\end{array}$ \\
\hline BARI Rca 201 & $38.33 \mathrm{c}$ & $54.37 \mathrm{bc}$ & $7.43 \mathrm{bc}$ & $1876 \mathrm{abc}$ \\
\hline BARI Rca 220 & $33.87 \mathrm{~d}$ & $49.10 \mathrm{c}$ & $6.83 \mathrm{~cd}$ & $1738 \mathrm{bc}$ \\
\hline BARI Rca 202 & $37.20 \mathrm{~cd}$ & $50.47 \mathrm{c}$ & $7.39 \mathrm{bc}$ & $1807 \mathrm{bc}$ \\
\hline BARI Chickpea Rajshahi & $47.80 \mathrm{a}$ & $71.63 \mathrm{a}$ & $9.58 \mathrm{a}$ & $2090 \mathrm{a}$ \\
\hline BARI Rca IC 59 & $46.93 \mathrm{ab}$ & $71.00 \mathrm{a}$ & $9.39 \mathrm{ab}$ & $2019 \mathrm{ab}$ \\
\hline BARI Chickpea pulse 1 & $43.27 \mathrm{~b}$ & $63.47 \mathrm{ab}$ & $8.70 \mathrm{abc}$ & $1946 \mathrm{abc}$ \\
\hline Control (Untreated) & $28.77 \mathrm{e}$ & $45.97 \mathrm{c}$ & $5.33 \mathrm{~d}$ & $1668 \mathrm{c}$ \\
\hline
\end{tabular}

In a column, similar letter does not differ significantly at $5 \%$ level of probability.

BARI = Bangladesh Agricultural Research Institute

Number of pod/plant, number of seeds/plant, weight of seeds/plant and yield of chickpea under BARI Rhizobium strains varied significantly from one to another during 2011-12 (Table 4). The highest number of pod/plant (37.87), number of seeds/plant (51.80), 
weight of seeds/plant (7.25 g) and yield (2040 kg/ha) were obtained from BARI Chickpea Rajshahi which was followed by BARI Rca IC 59 and BARI Chickpea pulse, and the lowest of these parameters were obtained from untreated control.

Table 4: Effect of BARI Rhizobium Biofertilizers on yield and yield contributing characters of Chickpea during 2011-12

\begin{tabular}{|l|c|c|c|c|}
\hline $\begin{array}{l}\text { Rhizobium } \\
\text { Biofertilizers }\end{array}$ & $\begin{array}{c}\text { No. of pod } \\
\text { / plant }\end{array}$ & $\begin{array}{c}\text { No. of seed } \\
\text { / plant }\end{array}$ & $\begin{array}{c}\text { Wt. of seed } \\
\text { /plant (g) }\end{array}$ & $\begin{array}{c}\text { Yield } \\
\text { (kg/ha) }\end{array}$ \\
\hline BARI Rca 201 & $27.60 \mathrm{c}$ & $40.40 \mathrm{bc}$ & $5.18 \mathrm{~cd}$ & $1825 \mathrm{abc}$ \\
\hline BARI Rca 220 & $21.27 \mathrm{de}$ & $33.86 \mathrm{de}$ & $4.31 \mathrm{ef}$ & $1668 \mathrm{~cd}$ \\
\hline BARI Rca 202 & $24.00 \mathrm{~cd}$ & $39.46 \mathrm{~cd}$ & $4.87 \mathrm{de}$ & $1758 \mathrm{bcd}$ \\
\hline BARI Chickpea Rajshahi & $37.87 \mathrm{a}$ & $51.80 \mathrm{a}$ & $7.25 \mathrm{a}$ & $2040 \mathrm{a}$ \\
\hline BARI Rca IC 59 & $33.07 \mathrm{~b}$ & $46.08 \mathrm{~b}$ & $6.14 \mathrm{~b}$ & $1968 \mathrm{ab}$ \\
\hline BARI Chickpea pulse 1 & $31.53 \mathrm{~b}$ & $44.13 \mathrm{bc}$ & $5.64 \mathrm{bc}$ & $1895 \mathrm{ab}$ \\
\hline Control (Untreated) & $19.93 \mathrm{e}$ & $30.11 \mathrm{e}$ & $3.93 \mathrm{f}$ & $1551 \mathrm{~d}$ \\
\hline
\end{tabular}

In a column, similar letter does not differ significantly at $5 \%$ level of probability. BARI = Bangladesh Agricultural Research Institute

From the above study, it has been observed that BARI Rhizobium strains showed significant effect on foot and root rot of chickpea during 2010-11 and 2011-12. Similar trends of the results were found in both the years. The lowest incidence of foot and root rot of chickpea was recorded in BARI Chickpea Rajshahi which was not statistically similar to all other treatment, but the highest incidence was recorded in untreated control. BARI Chickpea Rajshahi gave the highest plant survival and control treatment gave the lowest plant survival. BARI Chickpea Rajshahi treated plots reduced maximum foot and root rot incidence over untreated control. Hossain (2000) found that treatment of seeds with Biofertilizer resulted in 85.2 and 73.1\% reduction in death of plants due to infection by Fusarium oxysporum in lentil and chickpea, respectively, while Hossain et al. (2000) observed that the highest reduction (69.4\%) of Fusarial foot and root rot in chickpea over untreated control was with Rhizobium inoculation @ $50 \mathrm{~g} / \mathrm{kg}$ seed (when moistened with molasses). Khalequzzaman et al. (2010) found that BARI lentil 5 inoculated with BARI Biofertilizer Rlc 104 showed minimum (11.2\%) incidence of foot and root rot, leading to maximum plant survival (88.8\%). Hossain (2000) found that treatment of seeds with Biofertilizer also showed 76.7 and $87.0 \%$ reduction in death of plants of lentil and chickpea, respectively, due to infection by Sclerotium rolfsii. Arfaoui et al. (2005) reported that Rhizobium isolates protected chickpea plants from F. oxysporum. Hossain et al. (1999a) reported that treatment with Bavistin (0.2\%) and Biofertilizer (Rhizobium) @ $50 \mathrm{~g} / \mathrm{kg}$ seed resulted in the best control of seed borne fungi F. oxysporum of lentil. Huang and Erickson (2007) showed that treatment of seed with Rhizobium strains significantly reduced the incidence of damping off and increased the seedling height of chickpea. Khalequzzaman and Hossain (2008) conducted an experiment on foot and root rot of Bush bean with Rhizobium strains and Biofertilizers, and found that Rhizobium strain BINAR P36 largely controlled the foot and root rot of Bush bean. Kucuk (2013) showed the effects of 20 Rhizobium strains isolated from Phaseolus vulgaris L., Trifolium repens var. repens, Cicer arietinum L., Lens culinaris Medik., Vigna unguiculata L. and Phaseolus vulgaris L. 'Red Kidney' plants on mycelium growth of Fusarium oxysporum, F. moniliforme, F. solani, F. culmorum, F. oxysporum F1 strain, F.oxysporum F2 strain, F.oxysporum F3 strain, F.oxysporum F4 strain were observed on solid medium and found that the most Rhizobium strains were effective against the Fusarium species. Yaqub and Shahzad (2011) found that Sclerotium rolfsii showed significant negative effect on plant growth due to severe root colonization, whereas, presence of the microbial antagonists showed significant positive effect 
on plant growth by reducing the colonization of roots by S. rolfsii. Hannan (2012) found that BINA-biofertilizer and BAU-biofungicide (black gram bran-based Trichoderma harzianum) were compatible and had combined effects in controlling the pathogenic fungi Fusarium oxysporum and Sclerotium rolfsii, which cause the root rot of lentil. Post-emergence deaths of plants due to foot rot disease were significantly reduced after combined seed treatment with BINAbiofertilizer and BAU-biofungicide. Hannan et al. (2013) applied cowdung in soil and treated seed with BINA-Biofertilizer and BAU-Biofungicide and found that field emergence was higher up to $26.47 \%$, post-emergence deaths of plants due to foot rot disease were also successfully reduced in grasspea. Shaban and El-Bramawy (2011) exhibited that Rhizobium spp. and Trichoderma sp. fungi showed combined effects in controlling the fungi, which caused the damping off and root rot. Hoque et al. (2015) evaluated Rhizobium leguminosarum against foot and root rot pathogens Fusarium oxysporum and Sclerotium rolfsii of lentil. In dual culture method, the highest zone of inhibition of F. oxysporum $(57.37 \%)$ was measured against $R$. leguminosarum isolate. In paper towel test, a minimum number of dead seeds (9.00), no abnormal and diseased seedlings were counted from $R$. leguminosarum treated seeds. In water agar test tube test, minimum number of dead seed (12.00) and abnormal seedlings (2.00) were counted from R. leguminosarum treated seeds.

Number of pod/plant, number of seeds/plant, weight of seeds/plant and yield of chickpea under BARI Rhizobium strains varied significantly from one to another during 2010-11 and 2011-12. Similar trends of the results were found in both the years. The highest number of pod/plant, number of seeds/plant, weight of seeds/plant and yield were obtained from BARI Chickpea Rajshahi which was followed by BARI Rca IC 59 and BARI Chickpea pulse, and the lowest of these parameters were obtained from untreated control. Khalequzzaman and Hossain (2008) found that the tallest plant $(41.1 \mathrm{~cm})$ was observed in Rhizobium strain (BINAR P36) inoculated plots and the shortest plant (33.08 $\mathrm{cm}$ ) was in untreated control of Bush bean. Use of BINA-Biofertilizer and BAUBiofungicide as seed treating biocontrol agents and application of cowdung in the soil as an organic source of nutrient resulted higher plant stand, shoot and root length, and dry shoot and root weight of Grass pea (Hannan et al., 2013). Khalequzzaman and Hossain (2008) also found that the highest number of pods/plant (14.6) was recorded in case of using BINAR P36 inoculated plots and the lowest (7.8) in untreated control of Bush bean. Hossain et al. (1999b) reported that Rhizobium inoculants increased significantly pods/plant of lentil up to $42.1 \%$ over the untreated control. Rai and Singh (1979) stated that inoculation with Rhizobium bacteria led to a significant increase in seed yield of chickpea compared with the uninoculated control, but Harnadez and Hill (1983) observed that inoculation with Rhizobium strain CC 1192 increased seed yield of chickpea by 29\%, and Sandhu (1984) reported that lentil seed inoculation with Rhizobium culture improved yield by $8-22 \%$, but Pal and Ghosh (1986) reported that seed inoculation with Rhizobium leguminosarum strain L 25 and L 20 increased seed yield by $59.8 \%$ in lentil and up to $38.87 \%$ in chickpea. Seed inoculation with Rhizobium leguminosarum strain L 25 and L 20 increased seed yield by $59.8 \%$ in lentil and up to $38.87 \%$ in chickpea (Pal and Ghosh, 1986). Khalequzzaman (2008) found that Biofertilizer increased grain yield that was at par with the fungicides in lentil and chickpea. Khalequzzaman and Hossain (2008) conducted an experiment on foot and root rot of Bush bean with Rhizobium strains and Biofertilizers, and found that Rhizobium strain BINAR P36 produced higher green pod yield of Bush bean. Seed yield increase with Rhizobium Biofertilizer has also been reported by Hossain et al. (1999b), Solaiman (1999), Hossain and Mohammed (2002), and Kibria and Hossain (2002). Khalequzzaman et al. (2010) found that BARI lentil 5 inoculated with BARI Biofertilizer Rlc 
104 gave the highest yield (1952.9 kg/ha). Shaban and El-Bramawy (2011) exhibited that Rhizobium spp. and Trichoderma sp. fungi showed combined effects on improvement in many plant growth parameters, which are ultimately expressed in increasing the yield components of branches plant 1 , pods plant 1 , seeds pod-1, mean seed weight and then increase seed yield of the legume field crops: broad bean, chickpea and lupine plants.

\section{ConcLusion}

From the above study, it may be concluded that seed treatment with BARI Chickpea Rajshahi @ $40 \mathrm{~g} / \mathrm{kg}$ seeds showed better performance followed by BARI Rca IC 59 and BARI Chickpea pulse 1 in respect of foot and root rot disease control and increase yield of chickpea.

\section{REFERENCES}

Anonymous. 1989. Advances in Pulses Research in Bangladesh. Abstr. Second National Workshop on Pulses. 6-8 June 1989. Joydebpur, Gazipur, Bangladesh. p. 254.

Anonymous. 1989. Advances in Pulses Research in Bangladesh. Abstr. Second National Workshop on Pulses. 6-8 June 1989. Joydebpur, Gazipur, Bangladesh. p. 254.

Arfaoui, A.B. Sifi, M.E. Hasani, I. E. Hadrami, A. Boudabbous and M. Charif. 2005. Biochemical analysis of chickpea protection against Fusarium wilt afforded by two Rhizobium isolates. Plant Path. J. 4(1): 35-42.

Aycock, R. 1966. Stem rot and other diseases caused by S. rolfsii. Tech. Bull. No. 174. Agricultural Experimental Station, North Carolina State University, Raleigh. p. 202.

Begum, F. 2003. Integrated control of seedling mortality of lentil caused by Sclerotium rolfsii. MS Thesis. Department of Plant Pathology, Bangabandhu Sheikh Mujibur Rahman Agricultural University, Gazipur, Bangladesh.

Dey, T.K., M.S. Ali and N. Chowdhury. 1993. Vegetative growth and sporangia production in Phytopthora colocaseae. Indian J. Root crops 17 (2): 142-146.

Gomez, K. A. and A. A. Gomez. 1984. Statistical Procedures for Agricultural Research. 2nd ed., Intl. Rice Res. Inst., John Willy and Sons, New York, Chichester, Brisbane, Toronto, Singapore. pp. 187-240.

Gupta, A. 2006. Efficacy of bio-agents vs. fungicides on disease incidence in chickpea. Ann. Plant Prot. Sci. 14(2): 496-497.

Hannan, M. A. 2012. Integrated management of foot rot of lentil using biocontrol agents under field condition. J. Microbiol. Biotechnol. 22(7): 883-888.

Hannan, M. A., M. M. Hasan and I. Hossain. 2013. Impact of Dual Inoculations with Rhizobium and Trichoderma on Root Rot Disease and Plant Growth Parameters of Grasspea under Field Conditions. Persian Gulf Crop Protection 2(1): 1-9.

Harnadez, L.G. and G.D. Hill. 1983. Effect of plant population and inoculation on yield and yield component of chickpea. Agron. Soc. New Zealand 13 : 75-79.

Hoque, S., N. Sultana, A.N. Faruq, M.Z.R. Bhuiyan and N. Islam. 2015. In-vitro evaluation of selected bio-control agents against foot and root rot pathogens of lentil. Scholarly Journal of Agricultural Science 5(1): 8-15.

Hossain, I. 2000. Biocontrol of Fusarium oxysporum and Sclerotium rolfsii infection in lentil, chickpea and mungbean. BAU Res. Prog. 11: 61.

Hossain, I. and D. Mohammed. 2002. Seed treatment with Biofertilizer in controlling diseases of mungbean. BAU Res. Prog. 12: 34.

Hossain, I., M. A. Jalil, M. A. I. Khan and F. M. Aminuzzaman. 2000. Seed treatment with Rhizobium and N P K nutrition on disease incidence and yield of chickpea (Cicer arietinum L.). Bangladesh J. Seed Sci. \& Tech. 4 (1\&2): 1-6. 
Hossain, I., M.A.I. Khan and A.K. Podder. 1999b. Seed treatment with Rhizobium in controlling Fusarium oxysporum and Sclerotium rolfsii for biomass and seed production of lentil (Lens culinaris M.). Bangladesh J. Environ. Sci. 5: 61-64.

Hossain, M.D., M.B. Meah and M.K. Siddiqua. 1999a. Effect of seed treatment with Bavistin and Rhizobium on foot and root rot of lentil. Bangladesh J. Plant Path. 15(1 \& 2): 1-4.

Huang, H.C. and R.S. Erickson. 2007. Effect of seed treatment with Rhizobium leguminosarum on pythium damping off, seedling height, root nodulation, root biomass, shoot biomass, and seed yield of pea and lentil. J. Phytopath. 155(1): 31-37.

Khalequzzaman, K. M. and I. Hossain. 2008. Efficacy of Rhizobium strains and Biofertilizers for controlling foot and root rot and increasing green pod yield of Bush bean. Bangladesh Journal of Agricultural Research 33(4): 617-622.

Khalequzzaman, K. M. 2008. Effect of seed treating fungicides and Biofertilizers in the incidence of foot and root rot disease of lentil and chickpea. Annals of Bangladesh Agriculture 12(2): 39-44.

Khalequzzaman, K. M., M. R. Humauan, M. R. Khatun and M. J. Uddin. 2010. Effect of Rhizobium inoculation in controlling foot and root rots of lentil varieties. Journal of Lentil Research 4: 58-63.

Kibria, M.G. and I. Hossain. 2002. Effect of Biofertilizer and Rhizobium on foot and root rot disease and seed yield of mungbean. Bangladesh J. Seed Sci. \& Tech. 6 (1\&2) : 41-45.

Kloepper, J.W. and M.N. Schroth. 1978. Plant growth promoting rhizobacteria in radish. Proc. IV International Conference on Plant Pathogenic Bacteria. Gilbert-Clarey, Tours, France. pp. 879-882.

Kucuk, C. 2013. In vitro Antagonism of Rhizobium Strains Isolated from Various Legumes. Journal of Applied Biological Sciences 7 (1): 24-30.

Nikam, P.S., G.P. Jagtap and P.L. Sontakke. 2007. Management of chickpea wilt caused by Fusarium oxysporum f.sp. ciceri. African J. Agric. Res., 2(2): 692-697.

Pal, S.C and G. Ghosh. 1986. Response to lentil and chickpea to inoculation with different strain of Rhizobium leguminosarum. Environment and Ecology 4 (4): 630-632.

Rai, R. and A.N. Singh. 1979. Response of strains of Rhizobium, grain yield, protein and amino acid content of chickpea. J. Agril. Sci. UK 93 (3): 47-49.

Rovira, A.D. 1965. Interaction between plant roots and soil microorganisms. Ann. Rev. Microbiol. 19: 241-266.

Rovira, A.D. 1969. Plant root exudates. Bot. Rev. 35: 35-57.

Sandhu, P.S. 1984. Effect of sowing date, phosphorus level and herbicides on the response of Rhizobium inoculation in lentil. Lentil Abst. 1986 (1) $28: 3$.

Shaban, W. I. and M. A. El-Bramawy. 2011. Impact of dual inoculation with Rhizobium and Trichoderma on damping off, root rot diseases and plant growth parameters of some legumes field crop under greenhouse conditions. International Research Journal of Agricultural Science and Soil Science 1(3): 98-108.

Solaiman, A.R.M. 1999. Influence of Rhizobium inoculant, nitrogen and boron on nodulation, dry weight and grain yield of chickpea. Annals of Bangladesh Agric. 9 (1): 75-84.

Somasegaran, P. and H. J. Hoben. 1994. Handbook for Rhizobia : Methods in Legume-Rhizobium Technology. Springer-Verlag New York, Inc., 175 Fifth Avenue, New York, NY 10010, USA. pp. $337 \& 415$.

Yaqub, F. and S. Shahzad. 2011. Efficacy and persistence of micobial antagonists against Sclerotium rolfsii under field conditions. Pakistan Journal of Botany 43(5): 2627-2634. 